\title{
SEED MORPHOLOGY AND TESTA SCULPTURES OF SOME Allium L. SPECIES (Alliaceae)
}

\author{
Leszek Bednorz ${ }^{1}$, Agnieszka Krzymińska ${ }^{2}$, Aneta Czarna ${ }^{1}$ \\ ${ }^{1}$ Department of Botany, ${ }^{2}$ Department of Ornamental Plants, Poznań University of Life Sciences, \\ Wojska Polskiego 71c, PL-60-625 Poznań, Poland \\ e-mail: lbednorz@up.poznan.pl
}

Received: 17.01.2011

\begin{abstract}
The paper presents the results of the study on seed morphology of eight following Allium species: A. pyrenaicum Costa \& Vayr., A. rotundum L., A. sphaerocephalon L., A. vineale L., A. moly L., A. karataviense Regel, A. fistulosum L. and $A$. nutans $\mathrm{L}$. The study confirmed the substantial diversity in testa characters, especially curvature and relief of anticlinal walls as well as microsculpture of outer periclinal walls. The occurrence of raised anticlinal walls - an unusually rare feature in Allium seeds, previously observed only in a few species, was found in A. karataviense. It was also found that the testa type in A. pyrenaicum did not match the typical character combination, described before for subg. Allium sect. Allium.
\end{abstract}

Key words: Alliaceae, Allium, seeds, testa sculpture, SEM

\section{INTRODUCTION}

Allium L. is a large, very diverse and taxonomically difficult genus of the monocots. The genus comprises about 800 species belonging to 15 subgenera and 56 sections (Fries e $\mathrm{n}$ et al. 2006; N e shati and Frits ch, 2009). The most important subgenera are: Allium, Amerallium, Cepa, Melanocrommyum, and Rhizirideum. Most species occur naturally in the northern hemisphere with the main centre of diversity in Southwest and Central Asia. Allium includes many cultivated species - mostly ornamental plants but also economically important crop species and some with medicinal properties.

A high level of morphological diversity ascertained in the genus Allium concerns also seed testa characters whose details are well visible under the scanning electron microscope (SEM). A large number of different testa types have been described so far (e.g. Kruse, 1984, 1986, 1988, 1994; Frits ch et al. 2006; Neshati and Fritsch, 2009). Most of them occur only in certain systematic groups reflecting taxonomic relations and evolutionary levels (F r i t s c h et al. 2006). The other seed characters, such as colour, size and shape, were considered to be taxonomically rather unimportant characters in the genus Allium (Neshati and Fritsch, 2009).

The aim of the presented work was to describe testa sculptures of some selected Allium species, not investigated so far: A. pyrenaicum Costa \& Vayr., A. rotundum L., A. sphaerocephalon L., A. vineale L., A. moly L., A. karataviense Regel, A. fistulosum L., and A. nutans L. Micromorphological characters of seeds may be useful as additional taxonomic features in identification and distinguishing taxa within the genus Allium.

\section{MATERIALS AND METHODS}

Seeds of eight Allium species representing the most important five subgenera were investigated. Seeds were collected in natural localities, in a collection of Poznań University of Life Sciences, and in the Botanical Garden of Adam Mickiewicz University in Poznań (Table 1). All examinations were carried out on fully developed dry seeds. The seeds were not specially prepared, but only cleaned. Size (length and width), shape, outline, and seed colour were determined from 30 seeds of each species using a stereoscope microscope, PZO type 131. Five seeds of each species were mounted on aluminium stubs with "Leit-Tabs" and coated with gold in an Agar sputter coater. Electron micrographs were obtained with a Zeiss EVO 40 scanning electron microscope at an accelerating voltage of $12 \mathrm{kV}$. The terminology describing the seed surface followed mainly B a r th lot t $(1981,1984)$. 


\section{RESULTS}

The main macro- and micro-morphological characters of the investigated seeds are summarized in Table 2, and the selected SEM microphotographs of the seed showing a general view and testa details are presented in Figs 1-8.

\section{General morphological characters}

The seeds of all investigated species were black; matte in A. karataviense, and slightly shiny in the remaining species. The shape of seeds was generally angular; most often with four walls in A. fistulosum, three walls in A. sphaerocephalon, and two walls in the remaining species. The seed outline was very variable - elliptic, roundish, obovate, or wide ovate. The seeds of A. fistulosum were outstanding in this respect, because they were wider than longer. The average seed size ranged from $2.5 \mathrm{~mm}$ (A. vineale) to $3.1 \mathrm{~mm}$ (A. karataviense) in length and $1.4 \mathrm{~mm}$ (A. vineale) to $2.9 \mathrm{~mm}$ (A. karataviense) in width.
Thus, A. vineale had the smallest and A. karataviense the largest seeds.

\section{Shape and sculpturing of testa cells}

The shape of testa cells was very variable from elliptic and circular to polygonal and irregular. The anticlinal walls were usually depressed, except the raised ones in A. karataviense. They were more or less straight, strip-like in A. pyrenaicum (Fig. 1a), A. fistulosum (Fig. 7a) and A. nutans (Fig. 8a), and S-like, U-like or Omega-like undulated in the remaining species. Sculpturing patterns of the periclinal walls were not very variable among the species investigated. Most common were convex, granulose walls bearing several verrucae. A. pyrenaicum (Fig. 1a) had flat, distinctly granulose walls with a central verruca. A. moly (Fig. 5a) showed flat, not granulated walls, most often with one central verruca. A. fistulosum (Fig. 7a) had densely granulose walls with no verrucae, and $A$. $n u$ tans (Fig. 8a) were distinctive of very densely granulose walls and hidden, indistinct central verruca.

Table 1.

Origin of the material (taxonomic groups after Fries en et al. 2006)

\begin{tabular}{|c|c|}
\hline Taxonomic groups and species & Collection site \\
\hline \multicolumn{2}{|l|}{ subg. Allium } \\
\hline \multicolumn{2}{|l|}{ sect. Allium } \\
\hline A. pyrenaicum Costa \& Vayr. & Poznań, collection of Poznań University of Life Sciences \\
\hline A. rotundum $\mathrm{L}$. & Konarskie, Greater Poland Voivodeship \\
\hline A. sphaerocephalon $\mathrm{L}$. & Poznań, collection of Poznań University of Life Sciences \\
\hline A. vineale $\mathrm{L}$. & Błażejewo, Greater Poland Voivodeship \\
\hline \multicolumn{2}{|l|}{ subg. Amerallium } \\
\hline \multicolumn{2}{|l|}{ sect. Molium } \\
\hline A. moly L. & Poznań, collection of Poznań University of Life Sciences \\
\hline \multicolumn{2}{|l|}{ subg. Mellanocrommyum } \\
\hline \multicolumn{2}{|l|}{ sect. Miniprason } \\
\hline A. karataviense Regel & Poznań, collection of Poznań University of Life Sciences \\
\hline \multicolumn{2}{|l|}{ subg. Cepa } \\
\hline \multicolumn{2}{|l|}{ sect. Cepa } \\
\hline A. fistulosum L. & Poznań, Botanical Garden of Adam Mickiewicz University \\
\hline \multicolumn{2}{|l|}{ subg. Rhizirideum } \\
\hline \multicolumn{2}{|l|}{ sect. Rhizirideum } \\
\hline A. nutans L. & Poznań, Botanical Garden of Adam Mickiewicz University \\
\hline
\end{tabular}


Table 2.

Seed size and outline as well as characters of epidermal cells

\begin{tabular}{|c|c|c|c|c|c|}
\hline $\begin{array}{l}\text { Taxonomic } \\
\text { groups } \\
\text { and species }\end{array}$ & $\begin{array}{l}\text { Average seed } \\
\text { size - length } \\
\text { x width } \\
{[\mathrm{mm}]}\end{array}$ & $\begin{array}{c}\text { Dominant } \\
\text { seed outline }\end{array}$ & $\begin{array}{c}\text { Dominant } \\
\text { shape of testa } \\
\text { cells }\end{array}$ & $\begin{array}{l}\text { Anticlinal walls: } \\
\text { relief, } \\
\text { undulation type }\end{array}$ & $\begin{array}{c}\text { Periclinal walls: } \\
\text { curvature, } \\
\text { ornamentation }\end{array}$ \\
\hline \multicolumn{6}{|l|}{ subg. Allium } \\
\hline \multicolumn{6}{|l|}{ sect. Allium } \\
\hline A. pyrenaicum & $3.6 \times 1.9$ & elliptic & irregular & $\begin{array}{l}\text { depressed, } \pm \text { straight, } \\
\text { strip-like }\end{array}$ & $\begin{array}{l} \pm \text { plain, verrucate with } \\
\text { central verruca, distinctly } \\
\text { granulose }\end{array}$ \\
\hline A. rotundum & $2.6 \times 1.6$ & $\begin{array}{l}\text { elliptic, } \\
\text { obovate }\end{array}$ & elliptic & $\begin{array}{l}\text { depressed, } \\
\mathrm{S} \text { - to } \mathrm{U} \text { - like } \\
\text { undulation }\end{array}$ & $\begin{array}{l}\text { convex, verrucate with } \\
\text { many predominant verrucae, } \\
\text { granulose }\end{array}$ \\
\hline A. sphaerocephalon & $2.8 \times 1.7$ & obovate & $\begin{array}{l}\text { elliptic, } \\
\text { angularly round }\end{array}$ & $\begin{array}{l}\text { depressed, } \\
\text { omega-like undulation }\end{array}$ & $\begin{array}{l}\text { convex, verrucate with } \\
\text { many predominant verrucae, } \\
\text { slightly granulose }\end{array}$ \\
\hline A. vineale & $2.5 \times 1.4$ & elliptic & \pm elliptic & $\begin{array}{l}\text { depressed, } \mathrm{U}-\text { to } \\
\text { omega-like undulation }\end{array}$ & $\begin{array}{l}\text { convex, verrucate with many } \\
\text { predominant verrucae, rarely } \\
\text { granulose }\end{array}$ \\
\hline
\end{tabular}

subg. Amerallium

sect. Molium

A. moly $2.7 \times 2.4$ roundish irregular depressed, channel-like plain, verrucate, most often $\mathrm{S}$ - like undulation with central verruca, rarely with 2-4 verrucae

subg.

Mellanocrommyum

sect. Miniprason
A. karataviense
$3.1 \times 2.9$ roundish
elliptic to round
raised, $\mathrm{S}-$ to
convex, verrucate with
$\mathrm{U}$ - like undulation
4-10 prominent verrucae, granulose

subg. Cepa

sect. Cepa
A. fistulosum
$2.5 \times 2.8 \quad$ wide ovate
tetra- to
hexagonal
depressed, \pm straight, convex, densely granulose strip-like

\section{subg. Rhizirideum}

sect. Rhizirideum
A. nutans .
$2.7 \times 1.8$
roundish,
penta- to
hexagonal
shallowly depressed,
straight, strip-like
\pm convex, verrucate with elliptic central, hidden verruca, very densely granulose 

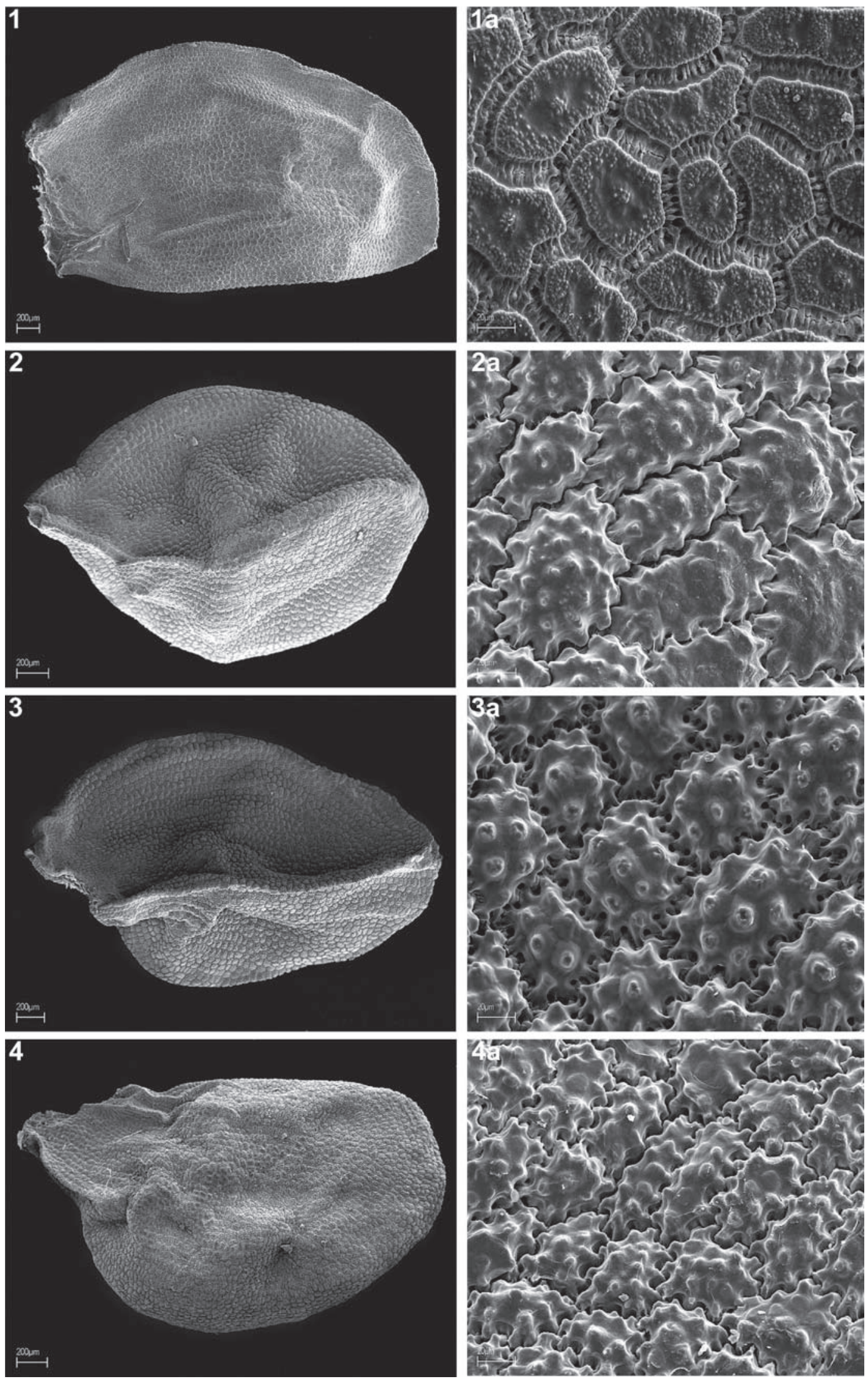

Figs 1-4. Micromorphological comparison of Allium seeds - general view and testa sculptures: 1, 1a - A. pyrenaicum, 2,2a - A. rotundum, 3, 3a-A. sphaerocephalon, 4, 4a-A. vineale. 

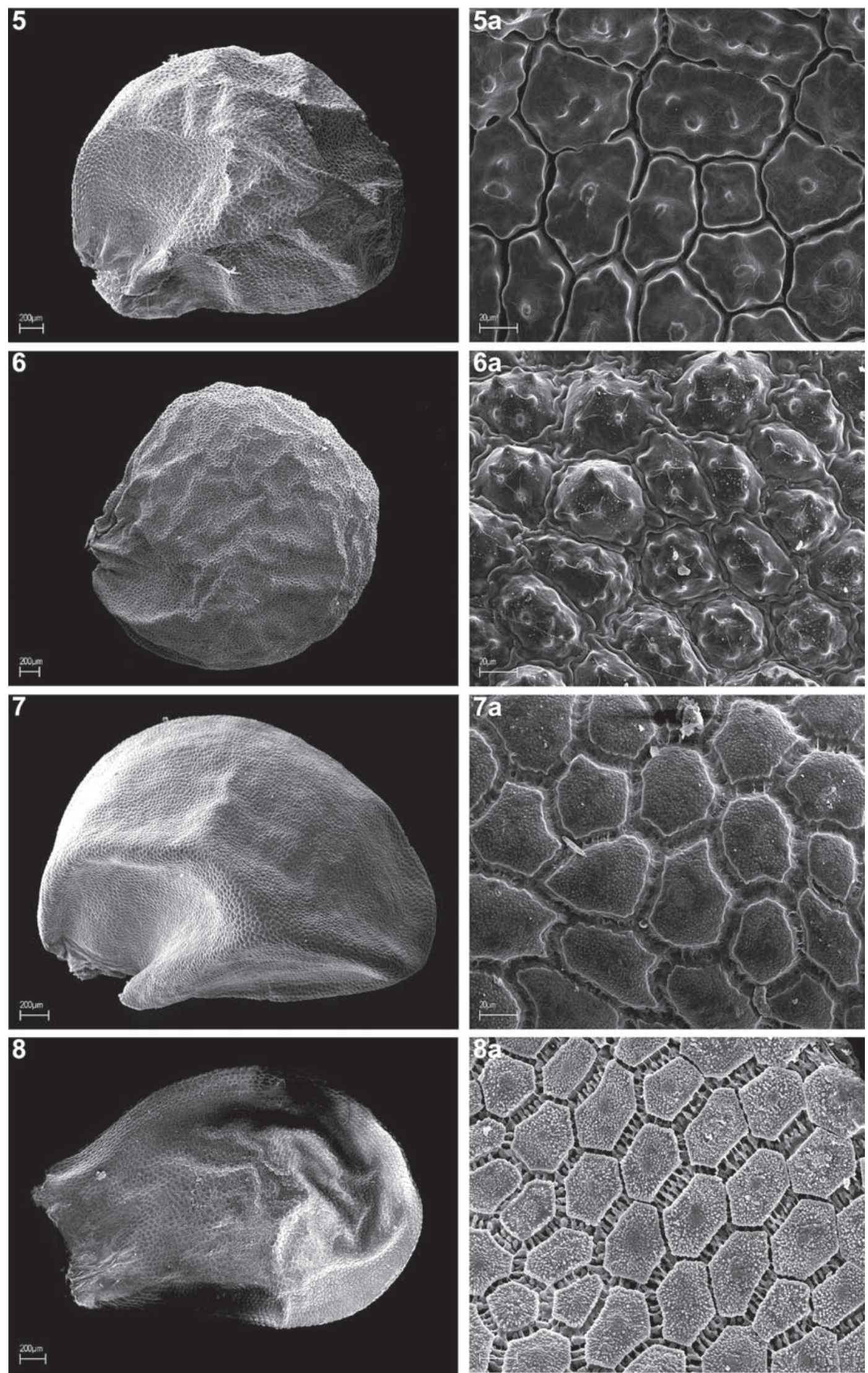

Figs 2-8. Micromorphological comparison of Allium seeds - general view and testa sculptures: 5, 5a-A. moly, 6, 6a-A. karataviense, 7, 7a-A. fistulosum, 8, 8a-A. nutans. 


\section{DISCUSSION}

Former studies on seed morphology have shown that testa sculptures have been very diverse and at the same time taxonomically important characters in the genus Allium. So far, the seed coat patterns of more than 250 Allium species have been investigated using SEM and many species- or group-specific character combinations have been described (Frits ch et al. 2006; Neshati and Fritsch, 2009). In the present study, seeds of eight Allium species representing six subgenera were investigated.

The seed testa cells of most species representing subgen. Allium and Mellanocrommyum (investigated so far) are rather similar, showing convex periclinal walls with several large verrucae, combined with depressed, S- to Omega-like, undulated anticlinal walls (Fritsch et al. 2006 after Kruse, 1992). The three species of subgen. Allium sect. Allium, investigated in the present study, match this character combination, while A. pyrenaicum shows convex periclinal walls with one central verruca, combined with nearly straight, strip-like anticlinal walls. A. karataviense, belonging to subgen. Mellanocrommyum, also breaks away from the pattern by the occurrence of raised anticlinal walls. This is an unusually rare feature in $\mathrm{Al}$ lium seeds, previously observed only in a few species, e.g. A. ursinum from subgen. Amerallium (K r u s e, 1984). According to Kruse (1988), the species of sect. Molium are characterized by wide, depressed, channel-like anticlinal walls and specific verrucate testa patterns with a distinctly raised central verruca surrounded by small granules. A. moly, described in the present paper, has anticlinal walls typical for sect. Molium but periclinal walls, although of similar verrucate sculpture, are more flat and non-granulate. The investigated species of sect. Cepa (A. fistulosum) and sect. Rhizirideum (A. nutans) with densely granulate periclinal walls represent the testa type typical for these sections (K r u s e, 1988, 1994).

\section{REFERENCES}

B a r th lot t W., 1981. Epidermal and seed surface characters of plants: systematic applicability and some evolutionary aspects. Nord. J. Bot. 1: 345-355.

B arthlott W., 1984. Microstructural features of seed surfaces. [In:] V. H. Heywood, D. A. Moore (eds) Current concepts in plant taxonomy. Academic Press, London.

Friesen N., Fritsch R.M., Blattner F.R., 2006. Phylogeny and new infrageneric classification of Allium
(Alliaceae) based on nuclear ribosomal DNA ITS sequences. Aliso, 22: 372-395.

Fritsch R.M., Kruse J., Adler K., Rutten T., 2006. Testa sculptures in Allium L. subg. Melanocrommyum (WEBB \& BERTH.) ROUY (Alliaceae). Feddes Repert. 117: 250-263.

Kruse J., 1984. Rasterelektronenmikroskopische Untersuchungen an Samen der Gattung Allium L. Kulturpflanze 32: 89-101 (in German).

Kruse J., 1986. Rasterelektronenmikroskopische Untersuchungen an Samen der Gattung Allium L. II. Kulturpflanze, 34: 207-228 (in German).

Kruse J., 1988. Rasterelektronenmikroskopische Untersuchungen an Samen der Gattung Allium L. III. Kulturpflanze, 36: 355-368 (in German).

Kruse J., 1994. Rasterelektronenmikroskopische Untersuchungen an Samen der Gattung Allium L. IV. Feddes Repert. 105: 457-471 (in German).

Neshati F., Fritsch R.M., 2009. Seed characters and testa sculptures of some Iranian Allium L. species (Alliaceae). Feddes Repert. 120: 322-332.

\section{Morfologia i skulptura powierzchni nasion wybranych gatunków rodzaju Allium L. (Alliaceae)}

\section{Streszczenie}

W pracy przedstawiono wyniki badań nad morfologią nasion ośmiu następujących gatunków rodzaju Allium: A. pyrenaicum Costa \& Vayr., A. rotundum L., A. sphaerocephalon L., A. vineale L., A. moly L., A. karataviense Regel, A. fistulosum L. i A. nutans L. Obserwacje wykonano z zastosowaniem elektronowego mikroskopu skaningowego (SEM) oraz mikroskopu stereoskopowego. Przeprowadzone badania potwierdziły znaczne zróżnicowanie cech powierzchni nasion czosnków, a w szczególności przebiegu i reliefu ścian antyklinalnych oraz mikro-urzeźbienia zewnętrznych ścian peryklinalnych komórek testy. U A. karataviense stwierdzono występowanie wypukłych ścian antyklinalnych komórek testy - cechy niezwykle rzadko spotykanej u czosnków, wcześniej zaobserwowanej zaledwie u kilku gatunków. Stwierdzono również, że typ skulptury nasion A. pyrenaicum nie odpowiada typowej kombinacji cech komórek testy, opisanej wcześniej u innych gatunków podrodzaju Allium sekcji Allium. 